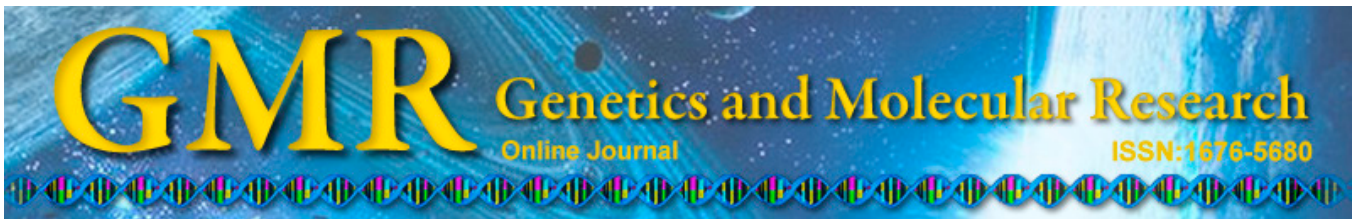

\title{
A suite of microsatellite markers for genetic management of captive cracids (Aves, Galliformes)
}

\author{
M.C. Costa ${ }^{1}$, C. Camargo ${ }^{1}$, N.M. Laganaro ${ }^{1}$, P.R.R. Oliveira Jr. ${ }^{1}$, \\ P.V. Davanço', R.M.A. Azeredo ${ }^{2}$, J.G.P. Simpson ${ }^{2}$, L.F. Silveira ${ }^{3}$ \\ and M.R. Francisco ${ }^{1}$ \\ ${ }^{1}$ Departamento de Ciências Ambientais, Universidade Federal de São Carlos, \\ Campus de Sorocaba, Sorocaba, SP, Brasil \\ ${ }^{2}$ CRAX, Sociedade de Pesquisa do Manejo e da Reprodução da Fauna Silvestre, \\ Contagem, MG, Brasil \\ ${ }^{3}$ Seção de Aves, Museu de Zoologia da Universidade de São Paulo, São Paulo, \\ SP, Brasil
}

Corresponding author: M.R. Francisco

E-mail: mercival@ufscar.br

Genet. Mol. Res. 13 (4): 9867-9873 (2014)

Received February 19, 2014

Accepted July 2, 2014

Published November 27, 2014

DOI http://dx.doi.org/10.4238/2014.November.27.14

\begin{abstract}
Cracids are medium to large frugivorous birds that are endemic to the Neotropics. Because of deforestation and overhunting, many species are threatened. The conservation of several species has relied on captive breeding and reintroduction in the wild, but captive populations may be inbred. Microsatellite tools can permit the construction of genetic pedigrees to reduce inbreeding, but only a few loci are available for this group of birds. Here, we present 10 novel polymorphic microsatellite loci and the cross-amplification of these and of 10 additional loci available in the literature in a panel of 5 cracid species, including 3 species with high conservation concern. We provide the first polymorphic loci for the jacutinga, Aburria jacutinga $(\mathrm{N}=8)$, and red-billed curassow, Crax blumenbachii $(\mathrm{N}=9)$, and
\end{abstract}


additional loci for bare-faced curassow, C. fasciolata $(\mathrm{N}=8)$, Alagoas curassow, Pauxi mitu $(\mathrm{N}=5)$, and razor-billed curassow, $P$. tuberosa $(\mathrm{N}=5)$. The average number of alleles was 2.9 for A. jacutinga, 2.7 for C. blumenbachii, 3.5 for C. fasciolata, 2.6 for P. mitu, and 5.7 for P. tuberosa. The mean expected heterozygosities were $0.42,0.40,0.48$, 0.37 , and 0.59 , respectively. The average probabilities that the set of loci would not exclude a pair of parents of an arbitrary offspring were $2.9 \%$ in A. jacutinga, $1 \%$ in C. blumenbachii, $0.5 \%$ in C. fasciolata, $0.4 \%$ in $P$. mitu, and $0.002 \%$ in $P$. tuberosa suggesting that these loci may be adequate for parentage analysis and to implement ex situ genetic management plans.

Key words: Galliformes; Endangered birds; Molecular markers; Parentage analysis; Genetic pedigrees

\section{INTRODUCTION}

Cracids (guans, chachalacas, and curassows) are medium to large frugivorous birds that are endemic to the Neotropics, where they play a significant role in tropical forest dynamics, especially through dispersing large-seeded plants (Sedaghatkish et al., 1999). Most species depends on large primary forest tracts, which make them highly vulnerable to habitat disturbance. For centuries, they also have been one of the major sources of proteins for subsistence hunters, and many populations were extirpated throughout their distributions. As a result, many species are vanishing, and 24 of the approximately 50 existing species are under some level of threat (Brooks and Fuller, 2006).

The conservation of a number of cracids has relied on captive breeding and reintroduction into the wild. Ongoing releasing programs of captive-bred individuals have reestablished populations of the endangered red-billed curassow, Crax blumenbachii (IBAMA, 2004; Bernardo et al., 2011), and of the jacutingas, Aburria jacutinga (Azeredo RA, unpublished results), in areas where they have become extinct. Other reintroduction programs have been planned to begin in the near future, and the most dramatic case is the Alagoas curassow, Pauxi mitu, which has been extinct in the wild since the late 1970s (Silveira et al., 2004).

Captive cracid populations were often started from a limited number of founders, either because they are difficult to capture alive or because there were no more individuals available in the wild (Silveira et al., 2004). This increases the risks that deleterious alleles become homozygous and lead to inbreeding depression, threatening the success of both captive breeding and reintroductions (Witzenberger and Hochkirch, 2011). The traditional approach to avoid inbreeding is minimizing the mating between closely related individuals following studbook data (Ballou and Foose, 1995). However, pedigree recordings are not available for the current captive cracid populations, although most of them were founded at least 2 decades ago. In these cases, molecular genetic analyses can provide accurate genetic pedigrees, as well as information on population genetic structure and variability (Witzenberger and Hochkirch, 2011). Thus, there is an urgent interest in implementing genetic monitoring programs for captive cracid populations that are intended to supply individuals for the ongoing and future 
reintroduction programs.

Polymorphic microsatellite loci are reliable tools for investigating individual relationships in both captive and wild populations (Stoeckle et al., 2012), but only a few loci are available for cracids (Hughes and Larson, 2000; Gonçalves et al, 2010; Sousa et al., 2013). Here, we present a set of novel and heterologous microsatellite loci isolated from cracid genomic libraries and we tested their applicability for parentage analyses in a panel of 5 cracid species, 3 of which have a high conservation concern. These markers include the first polymorphic loci for the endangered $C$. blumenbachii and A. jacutinga, and additional loci for the extinct in the wild P. mitu.

\section{MATERIAL AND METHODS}

We collected blood samples from 27-30 captive individuals of each studied species (Table 1). These animals were available in 3 private breeding facilities: CRAX - Sociedade de Pesquisa do Manejo e da Reprodução da Fauna Silvestre, Criadouro Científico e Cultural de Poços de Caldas, and CESP/Paraibuna. DNA was extracted using a standard phenol:cloroform protocol. To isolate new microsatellite loci, we generated an enriched library by digesting a genomic DNA sample of $A$. jacutinga with a restriction enzyme (RsaI; Promega, USA). DNA fragments were ligated to double-strand SNX linkers and hybridized with 8 biotinylated probes for dinucleotide repeats (Hamilton et al., 1999). Then, we selected DNA fragments containing potential microsatellites using magnetic beads (Streptavidin MagneSphere Paramagnetic Particles, Promega), and the enriched sample was cloned using TOPO TA Cloning Version P (Invitrogen Life Technologies). We sequenced 180 clones containing inserts in an ABI 3730 automated sequencer. Fluorescently labeled primers were designed for 22 microsatellite motifs consisting of at least 6 repeats using the Primer3 software program (Rozen and Skaletsky, 2000). We also designed primers for 15 new microsatellite motifs that were obtained from a genomic library previously developed for the razor-billed curassow, $P$. tuberosa, using the same methodology described above (see Sousa et al., 2013). We tested the broader use of these 37 loci and of an additional 10 loci available in the literature for P. tuberosa and P. mitu (Sousa et al., 2013). The loci were screened for polymorphism within and between the cloned species and in C. blumenbachii, bare-faced curassow, C. fasciolata, and P. mitu.

Polymerase chain reactions (PCRs) were performed in an Eppendorf MasterCycler Gradient thermal cycler in a $10-\mu \mathrm{L}$ volume containing $150 \mathrm{ng}$ DNA, $0.2 \mathrm{mM}$ of each dNTP, $1 \mathrm{X}$ PCR buffer (200 mM Tris-HCl, $\mathrm{pH} 8.4$, and $500 \mathrm{mM} \mathrm{KCl}), 0.2 \mu \mathrm{M}$ of each primer, 3 $\mathrm{mM} \mathrm{MgCl} 2$, and $1 \mathrm{U} \mathrm{Taq}$-polymerase. Amplification conditions were $94^{\circ} \mathrm{C}$ for $5 \mathrm{~min} ; 30$ cycles of $94^{\circ} \mathrm{C}$ for $30 \mathrm{~s}, 30 \mathrm{~s}$ at the annealing temperature specified in Table 1, and $30 \mathrm{~s}$ at $72^{\circ} \mathrm{C}$; and a final extension of $72^{\circ} \mathrm{C}$ for $10 \mathrm{~min}$. Amplified products were scored on an automated sequencer (ABI 3730).

We calculated the observed and expected heterozygosities, the probability of heterozygosity deficit, and linkage disequilibrium using GENEPOP 4.0 (Raymond and Rousset, 1995). Levels of significance for multiple tests were corrected through the sequential Bonferroni method (Rice, 1989). Evidence for null alleles was evaluated using Micro-Checker (Van Oosterhout et al., 2004). The suitability of the loci for parentage analysis was assessed 
for each species by calculating the average probability that the set of loci would not exclude a pair of candidate parents from parentage of an arbitrary offspring (PE), using the Cervus 3.0 software (Kalinowski et al., 2007).

\begin{tabular}{|c|c|c|c|}
\hline Locus & Primer sequence $\left(5^{\prime}-3^{\prime}\right)$ & Repeat motif & $\mathrm{Ta}\left({ }^{\circ} \mathrm{C}\right)$ \\
\hline \multirow{2}{*}{ Aburria 21} & GAGGATAAGCACGTCACAG & & \\
\hline & CAGCTAACTGGGTTTGAATCTG & $(\mathrm{CA})_{15}$ & 58.5 \\
\hline \multirow{2}{*}{ Aburria 22} & ATGCGCACTAATGAACAGTC & & \\
\hline & TCAGCTAGCCTTCCATTCCCTCAC & $(\mathrm{AG})_{5} \mathrm{G}(\mathrm{AG})_{10}$ & 58.5 \\
\hline \multirow{2}{*}{ Aburria 36} & AAGTAGATCACCACATGAG & & \\
\hline & CATTAAGGTGGTAACTTCAG & $(\mathrm{GT})_{5} \mathrm{~T}(\mathrm{GT})_{15}$ & 46.4 \\
\hline \multirow[t]{2}{*}{ Aburria 44} & TCCCTAGCAGATTCTGAGAC & & \\
\hline & CACCACAGGAACAGTGAG & $(\mathrm{GT})_{10}$ & 55.8 \\
\hline \multirow[t]{2}{*}{ Aburria 48} & ATTGGTAAAATGTATGATCAG & & \\
\hline & TGCAAATAGTTTCATAGCATCAG & $(\mathrm{TG})_{14}$ & 48.2 \\
\hline \multirow[t]{2}{*}{ Aburria 49} & TTCCTTTGGAATAGTGTGAG & & \\
\hline & ACAAATGAACTGCAGAAGC & $(\mathrm{CA})_{20}$ & 46.4 \\
\hline \multirow{2}{*}{ Aburria 105} & ACCATTTGCAGATTAGAC & & \\
\hline & ATCATCAGTGAAGAAACTG & $(\mathrm{TG})_{8}$ & 55.8 \\
\hline \multirow{2}{*}{ Pauxi 1-16 } & ATGAACAGCCATTGCATGAC & & \\
\hline & AGGCAGACATTAGCAGTG & $(\mathrm{GAAA})_{5}$ & 63.1 \\
\hline \multirow{2}{*}{ Pauxi 1-29 } & ACCATGTCTGGTTTCCT & & \\
\hline & ACTACATTGCTTCCTAACAG & $(\mathrm{GTTT})_{3} \mathrm{GG}(\mathrm{GTTT}) \mathrm{T}(\mathrm{GTTT})_{4}$ & 58.5 \\
\hline \multirow{2}{*}{ Pauxi 1-36 } & ACGATTCTGCAGTGAG & & \\
\hline & GTTATATCAAGTGTCCTCAG & $(\mathrm{AAAG})_{6}$ & 55.8 \\
\hline
\end{tabular}

\section{RESULTS}

Seven of the 22 loci isolated from A. jacutinga, and 3 of the 15 unpublished loci isolated from the $P$. tuberosa genomic library amplified and were polymorphic in at least 1 of the target species (Table 2). Of the 10 loci previously available in the literature for $P$. tuberosa and $P$. mitu, 9 presented polymorphism in other species. In total, we obtained 9 polymorphic loci for A. jacutinga, 9 for $C$. blumenbachii (the first described for these species), 10 additional loci for $C$. fasciolata, and 5 additional loci for P. mitu and P. tuberosa. We found significantly linked loci in A. jacutinga (Pauxi 1-4), C. fasciolata (Pauxi 1-37 and Pauxi 1-16), and P. tuberosa (Pauxi 1-37, Pauxi 2-7 and Pauxi 3-1), which were not used for parentage analysis.

The average number of alleles per polymorphic locus was 2.9 for A. jacutinga, 2.7 for C. blumenbachii, 3.5 for C. fasciolata, 2.6 for P. mitu, and 5.7 for P. tuberosa. The mean expected heterozygosities were $0.42,0.40,0.48,0.37$, and 0.59 , respectively (Table 2 ). MicroChecker indicated homozygote excess in loci Pauxi 3-4 for A. jacutinga; Pauxi 1-36 and Pauxi 3-4 for C. blumenbachii; Pauxi 1-16, Pauxi 1-29, and Pauxi 1-36 for C. fasciolata; and Aburria 21, Aburria 22, and Aburria 36 for P. tuberosa. However, we believe that heterozygote deficiencies in these loci may be due to inbreeding rather than null alleles. For instance, locus Pauxi 3-4 was fixed in 1 of 2 breeding facilities from which we obtained samples of $C$. blumenbachii, which represented 13 of the 30 analyzed individuals. Besides, individuals that failed to amplify completely (potentially homozygous for null alleles) were not found in any of the locus-species combinations. PE values were $2.9 \%$ for $A$. jacutinga, $1 \%$ for $C$. blumenbachii, $0.5 \%$ for C. fasciolata, $0.4 \%$ for P. mitu, and $0.002 \%$ for P. tuberosa. 


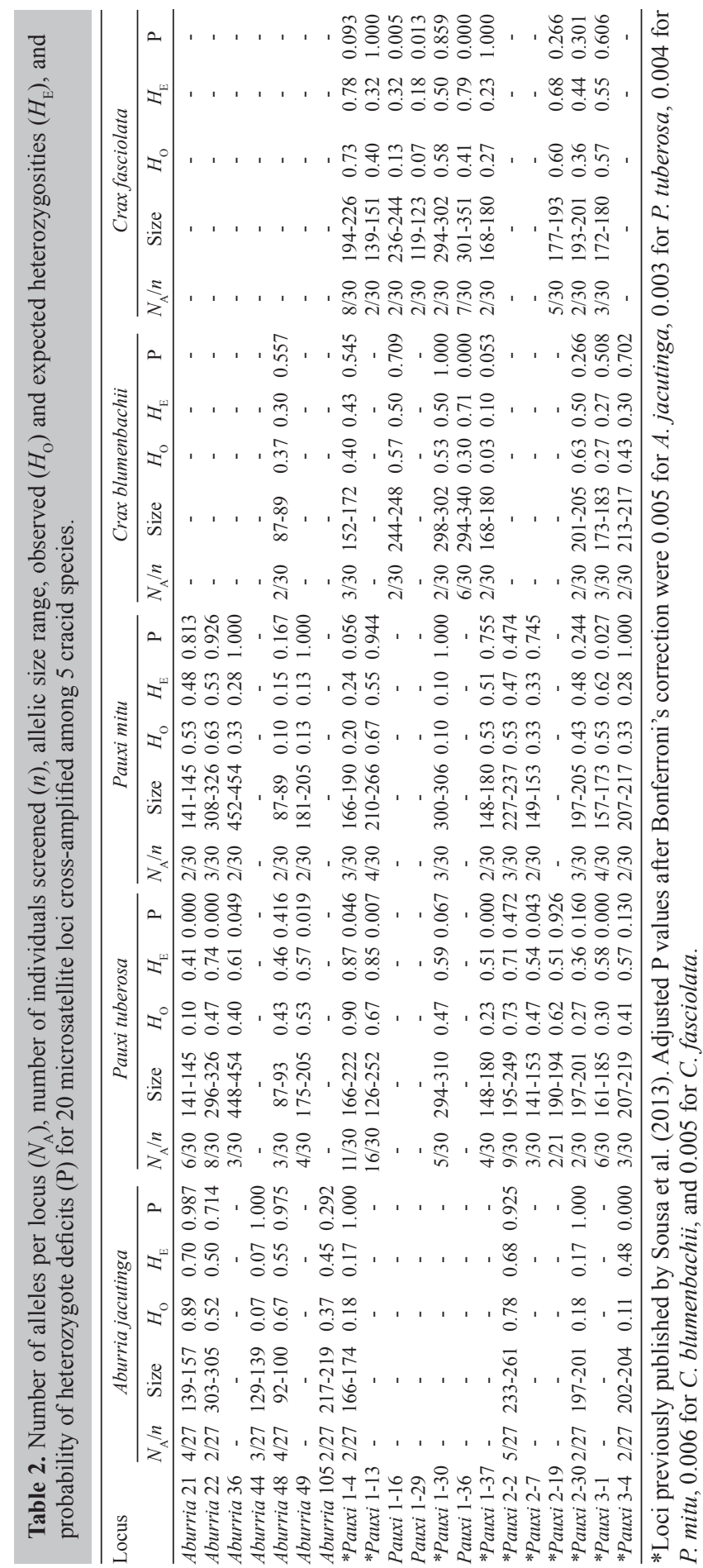




\section{DISCUSSION}

Cross-species amplification seemed to be a plausible alternative among cracids, with 19 of the 20 polymorphic loci showing transferability, often across genera, reducing the costs and time investment for the generation of polymorphic markers. Six loci that were monomorphic in the original species ( 2 from A. jacutinga and 4 from P. tuberosa) amplified and were polymorphic in other species.

The PE values varied among the studied species and sets of loci. Although some studies can reach probabilities of non-exclusion around $0.1 \%$ (Faircloth et al., 2010; Cherel et al., 2011), the populations that we analyzed invariably had a limited number of founders, and individuals must be related, weakening the analysis power (Jones et al., 2010). For this reason, we considered the PEs of $1 \%$ or less satisfactory, as the loci must be effective to resolve most of the assignments. The non-exclusion of more than 1 pair of potential parents must be more frequent in A. jacutinga, indicating the need of additional loci for this species.

The most critically endangered cracid species are those endemic to the Brazilian Atlantic forest (P. mitu, C. blumenbachii, and A. jacutinga). The current population of P. mitu is around 60 individuals living in 2 Brazilian breeding facilities, this species is one of the most endangered birds on earth. Most living individuals of $C$. blumenbachii are also in captivity. In 2004, when the captive population was 637 individuals, it was estimated that no more than 250 animals were living in the wild (IBAMA, 2004). Since captive breeding was demonstrated to be a feasible strategy to preserve cracids, Brazilian governmental authorities started to assist private captive breeding facilities and created official conservation action plans for these birds. The microsatellite markers presented here will contribute to the improvement of these official captive breeding programs by constructing genetic pedigrees, indicating individuals to be translocated among breeding facilities and allowing the selection of individuals for reintroduction in the wild based on their levels of heterozygosity and allelic diversity.

\section{ACKNOWLEDGMENTS}

We are grateful to Fundação de Amparo à Pesquisa do Estado de São Paulo (FAPESP \# 2008/51197-0, \#2010/08586-6, \#2011/06210-1) for financial support, ICMBio for authorizing sample collections, and Criadouro Científico e Cultural Poços de Caldas and CESP/Paraibuna for providing samples and logistical support.

\section{REFERENCES}

Ballou JD and Foose TJ (1995). Demographic and Genetic Management of Captive Populations. In: Wild Mammals in Captivity (Kleiman DG, Allen ME, Thompson KV and Lumpkin S, eds.). The University of Chicago Press, Chicago, 263-283.

Bernardo CSS, Lloyd H, Bayly N, Galetti M, et al. (2011). Modelling post-release survival of reintroduced Red-billed Curassows Crax blumenbachii. IBIS 153: 562-572.

Brooks DM and Fuller RA (2006). Biology and Conservation of Cracids. In: Conserving Cracids: the Most Threatened Family of Birds in the Americas (Brooks DM, ed.). Houston Museum of Natural Science, Houston, 10-22.

Cherel P, Glenisson J and Pires J (2011). Tetranucleotide microsatellites contribute to a highly discriminating parentage test panel in pig. Anim. Genet. 42: 659-661.

Faircloth BC, Title A, Tan K, Welty J, et al. (2010). Eighteen microsatellite loci developed from western burrowing owls (Athene cunicularia hypugaea). Conserv. Genet. Resour. 2: 167-171.

Gonçalves EC, Ferrari SF, Bastos HB, Wajntal A, et al. (2010). Comparative genetic diversity of wild and captive 
populations of the bare-faced curassow (Crax fasciolata) based on cross-species microsatellite markers: implications for conservation and management. Biochem. Genet. 48: 472-479.

Hamilton MB, Pincus EL, Di Fiore A and Fleischer RC (1999). Universal linker and ligation procedures for construction of genomic DNA libraries enriched for microsatellites. Biotechniques 27: 500-507.

Hughes CR and Larson ED (2000). Characterization of microsatellite loci developed for the wattled curassow, Crax globulosa. Mol. Ecol. 9: 632-633.

IBAMA (Instituto Brasileiro do Meio Ambiente e dos Recursos Naturais Renováveis) (2004). Plano de Ação para a Conservação do Mutum-do-Sudeste Crax blumembachii - Uma Espécie Bandeira para a Conservação da Mata Atlântica. IBAMA/MMA, Brasília.

Jones AG, Small CM, Paczolt KA and Ratterman NL (2010). A practical guide to methods of parentage analysis. Mol. Ecol. Resour. 10: 6-30.

Kalinowski ST, Taper ML and Marshall TC (2007). Revising how the computer program CERVUS accommodates genotyping error increases success in paternity assignment. Mol. Ecol. 16: 1099-1106.

Raymond $\mathrm{M}$ and Rousset $\mathrm{F}$ (1995). Genepop, Version 1.2: a population genetics software for exact tests and eucumenicism. J. Hered. 86: 248-249.

Rice WR (1989). Analyzing tables of statistical tests. Evolution 43: 223-225.

Rozen S and Skaletsky H (2000). Primer3 on the WWW for general users and for biologist programmers. Methods Mol. Biol. 132: 365-386.

Sedaghatkish G, Galetti M and Denny C (1999). The Importance of Pipile as a Seed Disperser of Economically Important Plants. In: Biology and Conservation of the Piping Guans (Pipile) (Brooks DM, Begazo AJ and Olmos F, eds.). IUCN Special Publications, Cracid Specialist Group, Houston, 4-12.

Silveira LF, Olmos F and Long AJ (2004). Taxonomy, history, and status of Alagoas Curassow Mitu mitu (Linnaeus, 1766), the world's most threatened cracid. Ararajuba 12: 43-50.

Sousa LMS, Laganaro NM, Camargo C, Davanço PV, et al. (2013). Microsatellite markers for detecting hybrids between the extinct in the wild alagoas curassow (Pauxi mitu) and razor-billed curassow (P. tuberosa) (Aves, Galliformes). Conserv. Genet. Resour. 5: 181-183.

Stoeckle BC, Theuerkauf J, Rouys S, Gula R, et al. (2012). Identification of polymorphic microsatellite loci for the endangered kagu (Rhynochetos jubatus) by high-throughput sequencing. J. Ornithol. 153: 249-253.

Van Oosterhout C, Hutchinson WF, Wills DPM and Shipley P (2004). MICRO-CHECKER: software for identifying and correcting genotyping errors in microsatellite data. Mol. Ecol. Notes 4: 535-538.

Witzenberger KA and Hochkirch A (2011). Ex situ conservation genetics: a review of molecular studies on the genetic consequences of captive breeding programmes for endangered animal species. Biodiv. Conser. 20: 1843-1861. 